\title{
Opening of Albanian Schools for Learning the Albanian Language in Kosovo During 1941-45
}

\author{
Ragip Gjoshi \\ University of Prizren "Ukshin Hoti"
}

\begin{abstract}
Difficult, long and troublesome was the journey of Albanian letters in all Albanian lands, especially in Kosovo. The marking of the 75th anniversary of the Albanian school, being commemorated this year in all Albanian lands, is a good opportunity to see the long-lasting path of Albanian education. There are many reasons, but some are more necessary to be written and spoken about. It is rare that nations had to pay dearly for the right to write on their own language compared to Albanian people. So much blood has been shed to escape assimilation. However, when World War II had spread largely over Europe, the Nazi-fascist powers had invaded other countries including all Albanian-inhabited areas. After Albania, Yugoslavia succumbed as well. At that time, the territories of today's Republic of Kosovo were also occupied. At that point, Kosovo was divided into three occupation zones: Italian, German and Bulgarian. Almost most of Kosovo's lands belonged to the Italian occupation zone. Thus, most of Kosovo and Western Macedonia joined Albania with Royal Decree and King of Vicar Decree no. 264, dated 12. VIII. 1941. ${ }^{1}$ In all three areas of occupation, the administration of governance was established in the service of the occupiers. The long and harsh oppression had an impact that Albanians would experience and perceive the new circumstances in every aspect as a resemblance of a real freedom, because the tyranny of the 1918-1941 period had exceeded all genocidal dimensions. ${ }^{2}$ With the initiative of Albanian Minister E. Koliqi, a contingent of teachers was sent to Kosovo as Kosovo lacked educationalpedagogical staff. This work set in motion the reflection of Albanian intelligence in Kosovo in order to open Albanian schools for Albanian students everywhere as soon as possible.
\end{abstract}

Keywords: Albanian language, school, teacher, curriculum, textbooks, teaching methods

\section{Introduction}

Kosovo began the 1941 with a new administrative arrangement. The area was divided into three occupation areas: Italian, German and Bulgarian. Most of Kosovo belonged to the Italian occupation zone. The administration was organized in the prefecture, such as: Pristina, Prizren, Peja, and Mitrovica. After this administration, Albanian bright minds were devoted to opening of schools. At this time in Kosovo and in Albanian lands, other state services such as finances, courts, administration, were held and conducted in Albanian.

Albanian Minister of Education Ernest Koliqi ${ }^{3}$, sent to Kosovo the first group of teachers, because Kosovo lacked educational-pedagogical staff. This work was compensated by the engagement of the imams and all those who knew the alphabet of Manastir. Besides the contingent of teachers from Albania, the former Albanian students who had studied in Serbo-Croatian or any other language ${ }^{4}$ were engaged in this valuable activity. Special courses were organized for the eradication of illiteracy and thus the desire for learning and using the Albanian language increased. During this time, as well as during the early years of the Albanian school, special importance has been given to teaching the Albanian language and history as a subject. Albanians regained the right to use national symbols etc. After 23 years of prohibition of schooling

\footnotetext{
${ }_{1}^{1}$ Ali Hadri, Okupacioni system nga Kosovu i Metohiji 1941-1944, Jugoslaavenski Istoriski Casopis, Belgrade, 1966, p. 7-9.

2 Ibidem p. 9

${ }^{3}$ In magazine Shejzat, no. August 1, 1957 and no. 4-5, November- December 1957, this giant writes about education and defines it as: ... new springs in Albanian parnas.

${ }^{4}$ In Kosovo and in the territories outside of Albania the spread of literacy was forbidden, sanctioned and punished until 1941 because the instruction was only allowed in Serbian or Macedonian languages.
} 
in Albanian, schools in Albanian language reopened in Kosovo. Primary education was five years and compulsory. During this period, in addition to hundreds of newly opened primary schools, the secondary school in Pristina also became operational. ${ }^{1}$ All of these institutions, including pedagogical courses for teacher qualification, contributed to educational and national awareness and to the alleviation of illiteracy and the spread of Albanian language learning. This was a very important period in the history of school development and education in Albanian language in Kosovo. ${ }^{2}$

\section{Challenges of education in Albanian language before 1941}

Learning the Albanian language in Kosovo is documented in the Middle Ages. There is evidence that the teaching of the Albanian language has started in religious educational institutions. The School of Stubla of Vitia (1584) ${ }^{3}$ is known for such method of organization. Therefore, the Albanian school has its roots since the 15th century. These were the first church schools open near the monasteries, known as City Schools, Latin Grammar Schools, Academies, Colleges, etc. (Stubëll, Pedhanë, Kurbin, Shkodër, etc.). The old textbooks used in schools have their origins from that time as well. Of that period was also the Gjon Buzuku's Meshari written in Latin alphabet.

The tradition of teaching Albanian language in Arabic alphabet is plausible to have existed in Kosovo. It was this period of opening foreign schools near churches, mosques and masjids that was consecutively followed by the National Renaissance period when the new mission for the Albanian bright minds of the time was arisen. It is an era that marks the interest of Albanians in science and education, for the knowledge, and freedom and liberation of the country. At this time the European pedagogical and didactic ideas penetrated in the Albanian lands as well. After the opening of the first national schools, these efforts were significantly increased in Kosovo. Nevertheless, after 1912 (after Kosovo's separation from Albania's trunk), this area was subject to oppression and violence. The use of Albanian alphabet was sanctioned. Those who were found having even a single ABC book in Albanian, were heavily punished and persecuted.

In 1914, the parts of Kosovo remaining under the Austro-Hungarian occupation were allowed to be instructed in Albanian and the Albanian Language and Literacy course took a major place in these schools, while in other parts of Kosovo's lands that were under the administration of Bulgarian rule, instruction in mother tongue was prohibited. Difficult times for the Albanian school and the Albanians in Kosovo begun to occur again. Thus, from 1918 to 1941 instruction and administration in Albanian language in Kosovo and Albania were prohibited.

The Circular for Education Inspectors of November 15, 1940 (On Language Learning in Elementary Schools), issued by the Minister of Education, Ernest Koliqi, was also important for the opening of schools in the areas outside of London Albania. Koliqi's, who at that time was the Minister of the Albanian Kingdom, appointed Ali Hashrova as the president of the Extraordinary Mission (education mission), Januz Blakçorri, vice-president and: Shaban Arrë, Zef Palin, Xhavit Nimanin and Fadil Hoxha as members, and Muharrem Musa as secretary ${ }^{4}$. This mission had devised a special mission program. ${ }^{5}$ The president of this mission, a competent school educator of the Albanian school in Kosovo, was committed to bringing high-minded national teachers to Kosovo. Around 600 Albanian teachers were introduced throughout Kosovo in several contingencies over the years, who helped to open Albanian schools and teach Albanian language. With regards to the execution of this mission, Koliqi noted: "In the summer of 1941, two hundred teachers of Old Albania (this is how the author called the homeland, my remarks, R. Gj.) were distributed into the Albanian population of the above mentioned areas and laid the foundations of national education". Most of these teachers remained in Kosovo until a large number of them were expelled by another decision from Yugoslavian politics. ${ }^{6}$ Albanian language was of particular importance in the curriculum of that time. To illustrate this, we emphasize the fact that in the first grade, Albanian language as a subject was taught 14 hours a week: letter development: 4 hours per week; literacy (speaking and writing): 5 hours per week; story telling: 2 hours per week; Speaking exercises: 2 hours per week; recitation: 1 hour per week. ${ }^{7}$ Even in

\footnotetext{
${ }_{1}^{1}$ Among the first secondary and vocational schools the distinguished ones were: Liceu i Shtetit Gjon Buzuku in Prizren, Agricultural Technical Institute - Peja Gymnasium, Shkolla Femnore e Punës 28 Nëntori (Women's School of Work), Gjon Kazazi School in Gjakova, Sami Frashëri School in Prishtina

2 Ali Hadri, LNÇ në Kosovë 1941-1945, Prishtina, 1971, p. 125

${ }^{3}$ Ragip Gjoshi, Shkolla e parë shqipe, shkolla e Stubllës, Malësia, 2014, p. 175

${ }^{4}$ Abdylaziz Veseli, Shkollat dhe arsimi shqip në Prefekturën e Prishtinës...1941-1944: II, Gjilan, 2003, p. 85

${ }^{5}$ AQSh, Fondi 295, year 1941, file 180, pages 7 and 8

${ }^{6}$ December 121941 is known to be the day of opening Abanian school in Kosovo.

${ }^{7}$ AQSh, Fondi 295, year 1941, file 27, page 48
} 
other elementary schools, the Albanian language as a learning subject was an important part of weekly plan of the classes and the content of the lesson. In the second grade, the Albanian language was taught 14 hours a week, in the third grade 14 , in the fourth grade 13 , and in the fifth 13 hours a week.

The dedication of the Albanian Ministry of Education for Education in Kosovo is best described through the content of the Circular, with some guidelines for patriotic education of students in elementary school, March 15, 1944, whereby Koco Muka is indicated as a minister but his goal was the same as Koliqi. These guidelines aimed the raising national awareness of Albanian students, calling on teachers not to be limited to regular teaching hours only. To plant and strengthen national education and conscience, with these instructions, it was required that the lower grade students be taught the following: simple, spiritually appropriate national poems for children; Light patriotic songs carefully taught; Simple events of national stories that are in the shape of tales told appropriately by the teachers; Simple stories about life and works of people spoken about in local and national history; Legends about places and objects of historical value, located in the province where the school operates; and Manifestations and classroom decorations for National Holidays. ${ }^{1}$

The students of the course cycle were subject to long instructions as well, this was summarized in seven important chapters, aiming to develop as powerful patriotic feelings in students as possible. The Ministry was continuously informed about the education developments in Kosovo. In a report of 25 July 1941 on educational activities, the Extraordinary Mission reported to Minister E. Koliqi: As soon as we arrived in Kosovo, we moved throughout Kosovo, both in the part of invaded by the Italian-Albanian troops as well as the part invaded by German troops, we came to contact with local authorities and the people to set the location of the course centers and the number of students for each course of Albanian language ${ }^{2}$ At that time, courses of Albanian language and other forms of adult education were organized all over Kosovo. Poems, recitals, dramatic dialogues, songs and gymnastics were being taught. The teaching staff that worked at these summer courses was paid well by the Ministry of Education in Tirana.

In Prizren only, there were 1200 children aged between 7-12 years that attended the summer courses. ${ }^{3}$ Such courses were organized throughout Kosovo. They were also organized for women. They were held also for the illiterates of different ages. ${ }^{4}$ Based on the evidence of that time, Albanian language began to be taught in almost all madrasahs. During 1941 only, this work was carried out by over 150 teachers from Albania and 27 teachers from Kosovo. They managed to teach the writing and reading of the Albanian language to over 28,000 attendants of all ages. Every year, there was an increasing need for the enhancement of curriculum content of educational work. Moreover, due to increased educational needs, pedagogical courses were opened in Kosovo in summer of $1942 .{ }^{5}$ The curriculum for these pedagogic courses had the following subjects: Albanian language: 9 hours per week; Albania's History and Geography: 4 hours per week; Songs: 2 hours; Psychology: 2 hours; Pedagogy: 4 hours; General didactics of special (methodical) didactics: 5 hours per week; Practical exercises (teaching practicum): 12 hours per week; 8 hours of hospice, 2 hours of independent course work, 2 hours of analytical and critical lessons for hospice. Final exams were held in front of four different commissions separately. ${ }^{6}$

On March 26, 1942, an agreement was reached in Mitrovica, whereby among other things, it was noted: The agreement was reached that all schools begin the work effective immediately. The schools and gymnasiums for Albanian children are to be opened straightaway. ${ }^{7}$ This was an act where the school and the Albanian education were officially legalized in the part of Kosovo which was under German occupation and which led to the opening of schools even in the deepest mountain villages. During 1941-1944 in Kosovo there had been a wider and more developed school network, with all the experiences of the grave past. Kosovo Albanians were diligently pursuing work to provide school premises and staff to work in newlyestablished schools.

\footnotetext{
1 Excerpt of Circular, with some instructions on patriotic education of students in primary schools, 15 March 1944, signed by Minister of Education, Koço Muka.

2 Preliminary Report on the Situation of Kosovo, on the Albanian Language Courses and on the Activity of the Extraordinary Mission (AQSh, FMA-295, year 1941, file 137, page 185).

3 Ibrahim Fehmiu, Mbyllja e kurseve të para shqipe në Kosovë, puna e kryer dhe detyrat e ardhshme të arsimit, gazeta Kosova, Tirana, 1941, no. 16, p. 4

${ }^{4}$ Abdylaziz Islami, Shkollat dhe arsimi shqip në Prefekturën e Prishtinës gjatë periudhës 1941-1945, Pristina, 2003, p. 469

${ }^{5}$ Based on the Decree no. 43 of February 28, 1942 of the Ministry of Education of Albania

${ }^{6}$ Report on the Pedagogical Course in Pristina (July-October 1942). (AQSh, p. 295, 1942, file. 235, p. 3)

${ }^{7}$ Arhiv Vonjo-istorijskog Instituta, Krajskomandatura 838, Kosovska Mitrovica, fig. 360-361, 16-III-1942
} 
In schools that were built, besides the teaching facilities, there were also residential homes for teachers. ${ }^{1}$ It was important that pupils were gathered and schooled in their mother tongue. In front of every school of this period, on the occasion of national holidays, national activities were being held: the academy, which began with the singing of the national anthem, to continue with the performance of various programs, such as recitals, acting and concerts prepared by students and teachers. The recitations of poems with patriotic content were very prominent. ${ }^{2}$ The schools of this period were completely wrapped with a spirit of patriotism. Lessons were taught about the nation, the flag, the homeland and Albania. Former schoolchildren of that time still express that teaching always began and ended with singing the national anthem. Attention was paid to wars of the Albanian people for independence. In these schools, the prominent personalities of our national movement, such as Ismail Qemali, Hasan Prishtina, Bajram Curri, Isa Boletini, Shote and Azem Galica were elevated. ${ }^{3}$

The doors of first schools in Kosovo were opened by teachers who came from Albania. ${ }^{4}$ During 1915-1918 a symbolic number arrived to be significantly increased during 1941-1944 and to continue most during 1946-1948. It is difficult to provide the exact number, but it is believed that the total number was over 700 . Nevertheless, a few years later the progressive circumstances for learning the Albanian language changed. When Tito Yugoslavia deteriorated the relations with the former USSR and with the eastern European countries in1948, 714 teachers coming from Albania were violently expelled from Kosovo. These teachers were replaced with Serbian and Montenegrin teachers. The overwhelming majority of them were unqualified teachers. ${ }^{5}$

\section{The Perspective of Albanian Language Learning for Kosovo Albanians, opening of Albanian Schools in 1941}

After the fall of the old Yugoslavia, Germans and Italians pushed the urgent need to build new governance. ${ }^{6}$ This administration allowed the use of Albanian language in state administration and in schools. Therefore, education was used as an instrument to satisfy the national patriotism of Albanians. Consenting the opening of Albanian schools, which would teach over $90 \%$ of the illiterate population, was well received.

A ray of hope for the Albanian alphabet and the Albanians of Kosovo and other Albanian territories under Yugoslavia was during the Second World War. The beginning of the school year 1941/42 brought great joy to Albanian children and instructors. In Albanian-language schools in Kosovo, teaching was conducted according to three curricula, depending on occupiers of areas. During the period between 1941 and 1944 most of the territory of Kosovo belonged to the Italian invasion, thus, in primary schools in these areas the instruction was taking place based on the curricula of the Ministry of Education of Albania. ${ }^{7}$

During this historical period, the elementary school curriculum was planned to be five years (five-grades). ${ }^{8}$ In the Albanian schools, special importance was given to teaching Albanian Language as a subject. This was the second institutional effort of learning the Albanian Language, which seems to be fundamental for Albanian education in Kosovo.

\begin{tabular}{|l|l|l|l|l|l|}
\hline Language lessons & \multicolumn{4}{|l|}{ Grades } \\
\cline { 2 - 7 } & I & II & III & IV & V \\
\hline
\end{tabular}

\footnotetext{
${ }_{1}^{1}$ AJ, f. MP, f. 464; d. br. 485/20-IV-1929 ((School facilities of this period could be divided into three groups: the schools that were set up during 1918-1941, the facilities of religious institutions, such as mosques, temples and other premises; remodeled and adapted premises in private homes).

2 See the narrative of an interlocutor in the work of prof. dr. Abdullah R. Vokrrit, Shkollat dhe arsimi në Kosovë ndërmjet dy luftërave botërore (1918-1941), Pristina, 1990.

${ }^{3}$ Hakif Bajrami, Rrethi i Llapit gjatë viteve 1941-1944, Prishtinë, 1975, defended thesis of masters degree.

${ }^{4}$ Musa Kraja, Mati Logoreci, Tirana, 1987, p. 29. (Starting with Mati Logoreci with his brother, Pashkon.) Until Mati opened the first Albanian school in Prizren (1888), Pashko went to Gjakova to open there the Albanian school as the first professional teacher who laid the foundation of education of Kosovo).

${ }^{5}$ Abdullah R. Vokrri, Ibrahim Kolqi, teacher and patriot, Pristine, 1993, p. 118-119

${ }^{6}$ Ali Hadri, Lufta Nacional Çlirimtare në Kosvovë, 1941-1945, Pristina, 196, p.134

${ }^{7}$ Abdylaziz Islami, Arsimi në gjuhën shqipe në Kosovë 1941-1945, Pristina, 2001

${ }^{8}$ According to this curriculum of Albanian language issued by the Ministry of Education in Albania, it was foreseen that 13 and 14 hours of lessons to be delieverd to Kosovo Albanian students.
} 


\begin{tabular}{|l|l|l|l|l|l|}
\hline Letter development & 4 & - & - & - & - \\
\hline Literacy & 5 & 5 & 5 & 4 & 4 \\
\hline Story telling & 2 & 2 & 2 & 1 & 1 \\
\hline Speaking exercises & 2 & 1 & 1 & 1 & 1 \\
\hline Reciting & 1 & 1 & 1 & 1 & 1 \\
\hline Essay writing & - & 2 & 2 & 3 & 3 \\
\hline Dictation & - & 2 & 2 & - & - \\
\hline Orthography & - & 1 & 1 & 3 & 3 \\
\hline Total hours per week & 14 & 14 & 14 & 13 & 13 \\
\hline
\end{tabular}

Table 1. The Albanian language course for five-grade elementary school students was divided into eight teaching sections. The fund of lessons based on sections. ${ }^{1}$

\section{Conclusion}

By shedding light on the history of Kosovo education during 1941-1944, I hereby present the facts about the educational activities in 1941-45. From the reports of schools and heads of education, it is studied that Albanian Language education and learning has occurred in many dimensions. Only in 1941, it is estimated that some 28,000 attendants of different ages had attended the courses organized for the eradication of illiteracy. According to archival records, in 1942, the Albanian Language education activity was conducted around 174 five-grade schools, which is the foundation of the Albanian school in these lands. The teaching work in these schools was carried out by teaching staff comprising of 359 teachers, with the number increasing every year. In 174 primary schools in the 1941/42 academic year, 15988 students attended the lessons, out of which 3,132 were girls. The second year of work and activity of the Albanian primary school, compared to the school year 1941/42, was on a higher scale. In the second academic year 1942/43 the number of primary school students increased by $4.52 \%$, the number of primary schools by 65 , or $27.19 \%$, and the number of teachers increased by 231 compared to 1941/42 academic year. The total number of working schools in Albanian was 239 in academic year 1942/43. In these schools attended 590 teachers (including 92 teachers) with 25,554 students $(20,513$ males or $80.4 \%$ and 5031 girls or $19.6 \%$ ).

The unsafe circumstances and war riots as well as social disorders were reflected in the routines of the school work during the academic year 1943/44. According to the annual work reports, in this academic year, compared to previous year, there was a decrease in the number of students from 25,544 to 20,846 or 4,698 less students, and the number of schools decreased from 239 to 221 or 18 less elementary schools. In the period between 1941-1944 in Kosovo and Macedonia for the first time in the history of Albanian education, 12 secondary and vocational schools in Albanian were opened and operated, involving 848 students (721 males and 127 females).

The textbooks of that time were mainly designed by Alexander Xhuvani, Eqrem Çabej, Rexhep Krasniqi, Ahmet Gashi, Karl Gurakuqi and others. An exceptional role among other Kosovo schools of this period had "Sami Frashëri" School in Prishtina. These years of instruction in Albanian language opened the door to the development of education in post-World War II Kosovo, the effects of which are observed even today.

\section{References}

[1] Bajrami, Hakif, Rrethi i Llapit gjatë viteve 1941-1944, Prishtinë, 1975

\footnotetext{
${ }^{1}$ According to the Circular of the Ministry of Education no. 971-118, dated 13. VI. 1941
} 
[2] Fehmiu, Ibrahim, Mbyllja e kurseve të para shqipe në Kosovë, puna e kryer dhe detyrat e ardhshme të arsimit, Gazeta Kosova, Tiranë, 1941

[3] Gjoshi, Ragip, Shkolla e parë shqipe, Shkolla e Stubllës, Malësia, 2014

[4] Hadri, Ali, LNÇ në Kosovë 1941-1945, Prishtinë, 1971

[5] Hadri, Ali, Lufta Nacional Çlirimtare në Kosovë 1941-1945, Prishtinë, 1966

[6] Hadri, Ali, Okupacioni system nga Kosovu i Metohiji 1941-1944, Jugoslaavenski Istoriski Casopis, Beograd, 1966

[7] Islami, Abdylaziz, Arsimi në gjuhën shqipe në Kosovë 1941-1945, Prishtinë, 2001

[8] Islami, Abdylaziz, Shkollat dhe arsimi shqip në Prefekturën e Prishtinës gjatë periudhës 1941-1945, Prishtinë, 2003

[9] Koliqi, Ernest, Tregtar flamujsh, Prishtinë, 1991

[10] Kraja, Musa, Mati Logoreci, Tiranë, 1987

[11] Kraja, Musa, Mësuesit për kombin shqiptar, Tiranë, 1993

[12] Plani për gjuhën shqipe nga Ministria e Arsimit e Shqipërisë

[13] Raport paraprak mbi gjendjen e Kosovës, mbi kurset e gjuhës shqipe e mbi veprimtarinë e Misionit të Jashtëzakonshëm (AQSh, FMA 295, viti 1941, dosja 137, fleta 185)

[14] Raport rreth kursit pedagogjik në Prishtinë (korrik-tetor1942), (AQSh, f. 295,viti 1942, dosja 235, f. 3)

[15] Rexha, Zekirja, Kosova, 24 maj 1941

[16] Shejzat, nr. 1, gusht 1957 dhe nr. 4-5, nanduer-dhetuer 1957

[17] Vokrri R., Abdullah, Ibrahim Kolqi, mësues dhe patriot, Prishtinë, 1993

[18] Vokrri R., Abdullah, Shkollat dhe arsimi në Kosovë ndërmjet dy luftërave botërore (1918-1941), Prishtinë, 1990

[19] Zajmi, Tahir, Tallazat e jetës dhe lotët e zemrës, Bruksel, 1970

\section{Bibliography}

[1] Arhiv Vonjo-istorijskog Instituta, Krajskomandatura 838, Kosovska Mitrovica, fig. 360-361. 16-III-1942

[2] AJ, f. MP, f. 464; d. br. 485/20-IV-1929

[3] AJ, Fond Ministravo prosvete i Vere, odeljenje za nemacku, nastavu, VI, br. 498/17-II-1943

[4] AQSh, Fondi 295, dosja 112

[5] AQSh, Fondi 295, viti 1941, dosja 16, fleta 8

[6] AQSh, Fondi 295, viti 1941, dosja 180, fleta 7 dhe 8

[7] AQSh, Fondi 295, viti 1941, dosja 27, fleta 48

[8] Dekret Mëkambësuer nr. 43, 28 shkurt 1942, Ministria e Arsimit e Shqipërisë

[9] Dekretligji Mbretëror dhe Dekretligj i Mëkëmbësit të Mbretit, nr. 264, 12. VIII. 1941

[10] Intervistë me mësuesin e vjetër nga Kishnareka, Beqir Bajraktari, 1987

[11] Qarkore e Ministrisë së Arsimit, nr. 971-118, datë 13. VI. 1941 
[12] Qarkore e Ministrisë së Arsimit, nr. 971-118, datë 13. VI. 1941-XIX

[13] Qarkore me disa udhëzime për edukatën patriotike të nxënësve në shkollën fillore, 15 mars 1944 